\title{
TITLE
}

\section{OPTIMIZING COVID-19 VACCINE USAGE}

Carlos Poblete Jara ${ }^{1,3,4}$, Lício A. Velloso ${ }^{2,3,4}$, Eliana Pereira de Araújo ${ }^{1,3,4}$

${ }^{1}$ Faculty of Nursing, ${ }^{2}$ Faculty of Medical Sciences, ${ }^{3}$ Laboratory of Cell Signaling, Obesity and Comorbidities Research Center, ${ }^{4}$ University of Campinas, Brazil

Carlos P. Jara (ORCID: 0000-0001-5444-721X)

Lício A. Velloso (ORCID: 0000-0002-4806-7218)

Eliana P. Araújo (ORCID: 0000-0002-7539-8477)

Corresponding author:

Carlos Poblete Jara,

Faculty of Nursing, University of Campinas, UNICAMP

Tessalia Vieira de Camargo St, 126 - 13083-887 Campinas - SP - Brazil

E-mail: blinkeado@gmail.com

Financial support: Coordination of Improvement of Higher-Level Personnel of Brazil

(CAPES)

Short running title: Optimizing COVID-19 vaccine wastage

Keywords: COVID-19; vaccine; sixth dose; optimization. 


\section{ABSTRACT}

As the worldwide vaccination, it is imperative to minimize vaccine wastage by effectively using all doses available. Vaccine wastage can occur at multiple points during the vaccination process, but it is mainly because the device dead space and the filling process technique. However, there are no studies discussing the waste volume effect of COVID-19 vaccines in clinical practice. There is an increasing COVID-19 vaccine demand that we estimate up to several billion dual doses. The objective of this study was to assess the number of $0.3 \mathrm{~mL}$ doses obtained from a multiple-dose vial using $1 \mathrm{ml}$ and $3 \mathrm{ml}$ syringes with different type of needles replicating the first COVID-19 vaccination protocol.

Our results suggest that it is possible to obtain six or seven doses from each vial instead five. We provide evidence to optimize between $20 \%$ and $40 \%$ additional vaccine doses per vial if the current 5-dose vials are used, making scarce supplies go further.

It is our duty, as researchers, to ensure the efficacy and efficiency of the worldwide COVID19 vaccination process. However, if standard syringes-needles and technique are used, there may not be sufficient volume to draw extra doses from a single vial. 
medRxiv preprint doi: https://doi.org/10.1101/2021.01.04.21249167; this version posted January 5, 2021. The copyright holder for this preprint (which was not certified by peer review) is the author/funder, who has granted medRxiv a license to display the preprint in perpetuity.

It is made available under a CC-BY 4.0 International license.

\section{INTRODUCTION}

SARS-CoV-2, the pathogenic agent of COVID-19, has had devastating consequences globally. Worldwide, COVID-19 overwhelm lifestyle, macroeconomic and threatens to affect billion human lives ${ }^{1-3}$.

The COVID-19 vaccination campaigns are being conducted to interrupt SARS-CoV-2 transmission and has shown efficacy in preventing COVID-19 illness ${ }^{4-9}$. Vaccines are needed to prevent COVID-19 and to protect people who are at high risk for complications ${ }^{4}$. Currently, there are only few companies producing COVID-19 vaccines, and optimization of usage could expand considerably the number of people immunized. There are currently not many manufacturers globally of COVID-19 vaccines to provide a short period proper number of vaccines for the world population. In this way, it is imperative to avoid vaccine wastages by effectively use all doses available. Vaccine wastage can occur at multiple points during the preparation, filling, and inoculation processes, but it is mainly because the device dead space and filling process technique ${ }^{10-15}$ :

One vital device is an appropriate syringe-needle system for delivering the vaccine. The association between needle-syringe system and waste were previously reported ${ }^{10,16,17}$. However, there are no publications discussing the waste volume effect of COVID-19 vaccines in clinical practice.

With the possibility of billions to be infected and the limited vaccine supply, it is essential that the syringe-needle system used waste as little as possible and consequently allow for a higher number of people vaccinated ${ }^{17}$.

Here, we assessed the number of doses draw from a multiple-dose vial, simulating the first COVID-19 vaccination protocol. Our goal was to optimize the COVID-19 vaccine wastage. We showed different syringe-needle system to use and we explored a no dead-volume approach to draw a seventh dose. 
medRxiv preprint doi: https://doi.org/10.1101/2021.01.04.21249167; this version posted January 5, 2021. The copyright holder for this preprint (which was not certified by peer review) is the author/funder, who has granted medRxiv a license to display the preprint in perpetuity.

It is made available under a CC-BY 4.0 International license.

\section{RESULTS}

\section{Syringe - needle system wastage}

We simulated the vaccination process pre-loading $0.45 \mathrm{~mL}$ of saline diluted with $1.8 \mathrm{~mL}$ of 0.9\% Sodium Chloride (Figure 1a). We found the mean dead-volume of the syringe - needle system ranged from $40 \mu \mathrm{L}$ to $560 \mu \mathrm{L}$ per vial (Table 1). The lower dead-volume was found in the no dead-volume group (Figure 1b, e) and the higher waste volume in the $3 \mathrm{ml}$ syringe23Gx1 needle group (Figure 1c, e). Also, we found the aspiration varied between needle Gauge and syringe system and ranged from $1.69 \mathrm{~mL}$ to $2.21 \mathrm{~mL}$ per vial (Table 1). Specifically, our results showed that the $3 \mathrm{~mL}$ syringe attached to $27 \mathrm{Gx} 1 / 2$ needle, increased the total volume recovered from the multiple-dose vial compared to the $3 \mathrm{~mL}$ syringe-23Gx 1 needle system (Table 1, Figure d).

Next, we showed that is possible to use every full dose, the sixth, or even a seventh dose from a multiple-dose vial. We obtained a sixth dose from each vial $50 \%$ of the times using a 3ml27Gx1/2 needle system for the dose extraction (Table 1, Fig. 1f).

Then, after we had stablished $27 \mathrm{Gx} 1$ needle is the best option for the doses withdraw, we compared $3 \mathrm{~mL}$ to $1 \mathrm{~mL}$ syringes. We identified that $1 \mathrm{~mL}$ syringe constantly improved the total volume recovered from the multiple-dose vial compared to $3 \mathrm{~mL}$ (Figure 1d). Also, $1 \mathrm{~mL}$ syringe decreased the dead-volume compared to $3 \mathrm{~mL}$ syringe (Figure 1e). Moreover, independently of the needle Gauge, $1 \mathrm{~mL}$ syringe constantly recovered six doses from the multiple-dose vial compared to $3 \mathrm{~mL}$ (Figure 1f). On the other hand, there is no differences in the number of doses draw, total volume, or dead volume collected by using $23 \mathrm{G}$ or $27 \mathrm{G}$ needles attached to a $1 \mathrm{~mL}$ syringe (Fig. 1d-f).

Finally, we obtained the seventh dose from a multiple-dose vial using a no dead-volume approach (Figure 1b, f). 
medRxiv preprint doi: https://doi.org/10.1101/2021.01.04.21249167; this version posted January 5, 2021. The copyright holder for this preprint (which was not certified by peer review) is the author/funder, who has granted medRxiv a license to display the preprint in perpetuity.

It is made available under a CC-BY 4.0 International license.

The data suggest that switching to $1 \mathrm{~mL}-23 \mathrm{G}$ system or to a no dead-volume approach from any of the others tested would provide between 20 and $40 \%$ additional vaccine doses per vial if the current 5-dose vials are used (Table 1)

\section{DISCUSSION}

Now, it is our duty, as physicians and nurses, to ensure the efficacy and efficiency of the worldwide COVID-19 vaccination process. However, if standard syringes-needles and technique are used, there may not be sufficient volume to draw extra doses from a single vial. Indeed, we learned this important lesson from the Influenza pandemic ${ }^{10,17}$.

If we only extracted five doses instead of six, as described on the vial label of the first FDA COVID-19 vaccine approved, we could lose up to 1.4 billion doses. In this way, we could waste not only doses, but priceless time, extending the vaccination campaign, billions of dollars, and most importantly, human lives. But not only the high dead-volume inside the syringes and needles could be a problem. In the vaccination practice, and according to the manufacturer ${ }^{18}$, any further remaining product inside the vial should not be pooled with other vial residue to obtain extra doses.

There is an increasing COVID-19 vaccine demand that we estimate up to 14 billion dual doses. We are on time to advise the public health authorities to make the best possible decision regarding to the syringe systems to face the COVID-19 vaccination process.

Remains pending for future studies to test different COVID-19 vaccines with low deadvolume syringe to evaluate the number of doses obtained as previously described ${ }^{17}$. 
medRxiv preprint doi: https://doi.org/10.1101/2021.01.04.21249167; this version posted January 5, 2021. The copyright holder for this preprint (which was not certified by peer review) is the author/funder, who has granted medRxiv a license to display the preprint in perpetuity.

It is made available under a CC-BY 4.0 International license.

\section{METHODS}

This study did not include human subject research, then, institutional review board authorization was not necessary ${ }^{16}$. We used $0.9 \%$ Sodium Chloride, two types of needles and two types of high dead-volume syringes for effectiveness analysis. All experiments in quadruplicate.

\section{Dose Preparation and dilution}

For the procedure involved $1 \mathrm{~mL}$ and $3 \mathrm{~mL}$ syringes (Nipro syringe) we used a 27 Gauge 1/2 “needle $(0.4 \times 13 \mathrm{~mm})$ and a 23 Gauge 1 " needle $(0.6 \mathrm{~mm} \times 25 \mathrm{~mm})$, all systems used with luer lock.

Four different syringe-needle system were tested (Figure 1a): $1 \mathrm{~mL}$ syringe attached to 23- or $27-G a u g e$ needle and $3 \mathrm{~mL}$ syringe attached to 23 - or 27 -Gauge needle (23G or $27 \mathrm{G}$ respectively). To quantify the number of microliters recovered from the vials, we calculated the number of syringes filled in with $0.3 \mathrm{~mL}$ of solution times 0.3 plus the last dose extracted using a $1 \mathrm{~mL}$ syringe.

Clean and dry $5 \mathrm{~mL}$-vials capacity (FluQuadri, Sanofi Medley) were used for all experiments. $0.45 \mathrm{~mL}$ of $0.9 \%$ Sodium Chloride (Baxter, for IV Infusions in Viaflex Container) was loaded in one vial using a $1 \mathrm{~mL}$ syringe $-23 \mathrm{G}$ needle system representing the undiluted vial. $1.8 \mathrm{~mL}$ 0.9\% Sodium Chloride was diluted in the $0.45 \mathrm{~mL}$ "undiluted vial" using a $3 \mathrm{~mL}$ syringe-23G needle system. We made sure to remove all air prior to drawing up. We used new needles and syringes in each draw, mimicking a vaccination procedure.

\section{No dead-volume approach}

We considered syringe-needle dead space was the volume of residual fluid that remains within the syringe-needle system after the plunger is fully depressed during inoculation ${ }^{11,16}$. A different technique for the no dead-volume approach was used by considering $0.0 \mathrm{~mL}$ as the starting point and filled in until 0.3 milliliters (Figure $1 \mathrm{~b}$ left). After $0.3 \mathrm{~mL}$ reached, an 
extra 0.1-0.2 $\mathrm{mL}$ air volume was added to force all fluid draw out the syringe-needle system.

The air volume was positioned in the plunger side of the syringe (Figure $1 \mathrm{~b}$ right).

\section{Statistical Analysis}

The data are presented as the mean \pm S.D. We used one-way ANOVA to compare more than two groups. $\mathrm{P}<0.05$ was considered statistically significant. Tukey's test for multiple comparison. We used GraphPad Prism 9 for Windows to perform statistical analysis. Graphical representation were created with BioRender.com . 
medRxiv preprint doi: https://doi.org/10.1101/2021.01.04.21249167; this version posted January 5, 2021. The copyright holder for this preprint (which was not certified by peer review) is the author/funder, who has granted medRxiv a license to display the preprint in perpetuity.

It is made available under a CC-BY 4.0 International license .

\section{Bibliography}

1. Kassa MD, Grace JM. Race against death or starvation? COVID-19 and its impact on African populations. Public Health Rev 2020;41(1):30. (In eng). DOI: 10.1186/s40985-020-00139-0.

2. Graso M, Chen FX, Reynolds T. Moralization of Covid-19 health response: Asymmetry in tolerance for human costs. J Exp Soc Psychol: (c) 2020 Elsevier Inc. All rights reserved.; 2020:104084.

3. Mei Q, Wang AY, Bryant A, et al. Development and validation of prognostic model for predicting mortality of COVID-19 patients in Wuhan, China. Scientific Reports 2020;10(1):22451. DOI: 10.1038/s41598-020-78870-6.

4. Baden LR, El Sahly HM, Essink B, et al. Efficacy and Safety of the mRNA-1273 SARS-CoV-2 Vaccine. New England Journal of Medicine 2020. DOI: 10.1056/NEJMoa2035389.

5. Widge AT, Rouphael NG, Jackson LA, et al. Durability of Responses after SARSCoV-2 mRNA-1273 Vaccination. New England Journal of Medicine 2020. DOI: 10.1056/NEJMc2032195.

6. Keech C, Albert G, Cho I, et al. Phase 1-2 Trial of a SARS-CoV-2 Recombinant Spike Protein Nanoparticle Vaccine. New England Journal of Medicine 2020;383(24):2320-2332. DOI: 10.1056/NEJMoa2026920.

7. Walsh EE, Frenck RW, Falsey AR, et al. Safety and Immunogenicity of Two RNABased Covid-19 Vaccine Candidates. New England Journal of Medicine 2020;383(25):2439-2450. DOI: 10.1056/NEJMoa2027906.

8. Polack FP, Thomas SJ, Kitchin N, et al. Safety and Efficacy of the BNT162b2 mRNA Covid-19 Vaccine. New England Journal of Medicine 2020;383(27):2603-2615. DOI: 10.1056/NEJMoa2034577.

9. Anderson EJ, Rouphael NG, Widge AT, et al. Safety and Immunogenicity of SARSCoV-2 mRNA-1273 Vaccine in Older Adults. New England Journal of Medicine 2020;383(25):2427-2438. DOI: 10.1056/NEJMoa2028436.

10. Jarrahian C, Rein-Weston A, Saxon G, et al. Vial usage, device dead space, vaccine wastage, and dose accuracy of intradermal delivery devices for inactivated poliovirus vaccine (IPV). Vaccine 2017;35(14):1789-1796. (In eng). DOI: 10.1016/j.vaccine.2016.11.098.

11. Oramasionwu CU, Cole AL, Dixon MS, et al. Estimated Cost of Injectable Medication Waste Attributable to Syringe Dead Space. JAMA Intern Med 2016;176(7):1025-7. (In eng). DOI: 10.1001/jamainternmed.2016.2301.

12. Bach PB, Conti RM, Muller RJ, Schnorr GC, Saltz LB. Overspending driven by oversized single dose vials of cancer drugs. Bmj 2016;352:i788. (In eng). DOI: 10.1136/bmj.i788.

13. Zule WA, Ticknor-Stellato KM, Desmond DP, Vogtsberger KN. Evaluation of needle and syringe combinations. J Acquir Immune Defic Syndr Hum Retrovirol 1997;14(3):294-5. (In eng). DOI: 10.1097/00042560-199703010-00015.

14. Berne C, Agenäs I, Eriksson G, Wibell L. Insulin wastage in ambulant practice. Diabetes Care 1984;7(4):343-6. (In eng). DOI: 10.2337/diacare.7.4.343.

15. Shainfeld FJ. Errors in insulin doses due to the design of insulin syringes. Pediatrics 1975;56(2):302-3. (In eng).

16. Golan S, Pena J, Moore J, Tandalam S, Lelli G. The Association between Needle Size and Waste Product and Its Effect on Cost-Effectiveness of Botulinum Toxin Injections? Facial Plast Surg 2020;36(4):484-486. (In eng). DOI: 10.1055/s-00401713793. 
medRxiv preprint doi: https://doi.org/10.1101/2021.01.04.21249167; this version posted January 5, 2021. The copyright holder for this preprint (which was not certified by peer review) is the author/funder, who has granted medRxiv a license to display the preprint in perpetuity.

It is made available under a CC-BY 4.0 International license.

17. Strauss K, van Zundert A, Frid A, Costigliola V. Pandemic influenza preparedness: the critical role of the syringe. Vaccine 2006;24(22):4874-82. (In eng). DOI: 10.1016/j.vaccine.2006.02.056.

18. Pfizer-BioNTech. FACT SHEET FOR HEALTHCARE PROVIDERS ADMINISTERING VACCINE

(VACCINATION PROVIDERS). In: Pfizer-BioNTech, ed. USA2020. 
medRxiv preprint doi: https://doi.org/10.1101/2021.01.04.21249167; this version posted January 5, 2021. The copyright holder for this preprint (which was not certified by peer review) is the author/funder, who has granted medRxiv a license to display the preprint in perpetuity.

It is made available under a CC-BY 4.0 International license.

\section{ACKNOWLEDGEMENTS}

The authors are grateful to Gladys Paredes Ulloa, Carlos Castro, Patricia Nilo, Jocelyn Araya, CESFAM Sarmiento and Ilustre Municipalidad de Curico. for technical assistance and financial support. This study was supported, in part, by the Coordenação de Aperfeiçoamento de Pessoal de Nível Superior - Brasil (CAPES) - Finance Code 88882.434714/2019-01.

\section{CONFLICTS OF INTEREST}

No conflicts of interest

\section{AUTHOR CONTRIBUTIONS}

CPJ: Conceptualization, Formal analysis, Methodology, Investigation, Writing - Original Draft, Writing - Review \& Editing

LAV: Formal analysis, Writing - Review \& Editing, Supervision

EPA: Conceptualization, Methodology, Formal analysis, Resources, Writing - Original Draft, Writing - Review \& Editing, Supervision

\section{FIGURES}

\section{Figure 1}

Experimental design and syringe-needle comparison. Schematic of testing process (a); Filled syringe-needle system with and without dead-volume (b). Total recovery of $0.9 \%$ Sodium Chloride from a $2.25 \mathrm{~mL}$ filled vial using different syringe-needle systems (c); Total dead-volume of $0.9 \%$ Sodium Chloride from a $2.25 \mathrm{~mL}$ filled vial using different syringeneedle systems (d); Percentage of doses recovered from a $2.25 \mathrm{~mL}$ filled vial using different syringe-needle systems (e). 
Table 1

\begin{tabular}{cccccccc} 
syringe & needle & \multicolumn{1}{c}{ recovered dead volume } & doses & $\% \mathbf{5}$ doses $\% \mathbf{6}$ doses $\% \mathbf{7}$ doses \\
\hline $1 \mathrm{ml}$ & $27 G \times 1 / 2$ & $1,87 \pm 0.02$ & $0,38 \pm 0.02$ & 6 & 100 & 100 & 0 \\
$1 \mathrm{ml}$ & $23 G \times 1$ & $1,84 \pm 0.02$ & $0,41 \pm 0.02$ & 6 & 100 & 100 & 0 \\
$3 \mathrm{ml}$ & $23 G \times 1$ & $1,69 \pm 0.04$ & $0,56 \pm 0.04$ & 5 & 100 & 0 & 0 \\
$3 \mathrm{ml}$ & $27 G \times 1 / 2$ & $1,83_{ \pm} 0.08$ & $0,42 \pm 0.08$ & 5,5 & 100 & 50 & 0 \\
$3 \mathrm{ml}$ & $23 G \times 1(\mathrm{a})$ & $2,21 \pm 0.05$ & $0,04 \pm 0.05$ & 7 & 100 & 100 & 100 \\
\hline
\end{tabular}

\section{Table 1}

Recovered: mean value of fluid withdraws from each vial. Dead volume: mean value of the difference between the $2.25 \mathrm{~mL}$ initial load and the recovered fluid from each vial. Doses: mean value of number of doses from each vial. $\%>5$ doses, $\%>6$ doses, and $\%>7$ doses: percentage of times reaching the pointed value. (a): no dead-volume approach. Mean values $\underline{ \pm}$ Standard deviation. All experiments in quadruplicate. 
